Pp. 2-16

DOI: http://dx.doi.org/10.24093/awejtls/vol5no4.1

\title{
In a Melting Pot of Autobiography: Pickthall's With the Turk in Wartime and the Cause of Islam
}

\author{
Ebtisam Ali Sadiq \\ Department of English language and Literature \\ King Saud University \\ Riyadh, Saudi Arabia \\ Email: esadiq@ksu.edu.sa
}

Received: 8/22/2021

Accepted: 9/12/2021

Published: 10/24/2021

\begin{abstract}
:
Marmaduke Pickthall, a half-forgotten British novelist of the early twentieth century, has come back to the spotlight over the past few years. His Near Eastern novels and short stories have started to receive attention in contemporary scholarship but not his two autobiographies. This essay aims at tackling the more neglected piece of the two, With the Turk in Wartime, that deserves attention because of its intricate amalgamation of several features of the genre of autobiography as manifested across its history within the tradition of English literature. Analysis finds that Pickthall's autobiography has some Romantic, Victorian, and Modern elements as well as some old characteristics of the genre elaborately interwoven into its structure. The study also traces the use that Pickthall makes of this unique autobiography and how the commingling of diverse elements allows him to turn a usually subjective genre into a public cause and dedicate it to the service of Islam. This essay highlights both the diversity that the literary history of the genre lends to Pickthall's autobiography and the socio-political service it renders to the faith that the author has long esteemed and will ultimately convert to not long after writing this autobiography.
\end{abstract}

Keywords: Autobiography, Marmaduke Pickthall, With the Turk in Wartime

Cite as: Sadiq, E. A. (2021). In a Melting Pot of Autobiography: Pickthall's With the Turk in Wartime and the Cause of Islam. Arab World English Journal for Translation \& Literary Studies 5 (4) 2-16. DOI: http://dx.doi.org/10.24093/awejtls/vol5no4.1 


\section{Introduction:}

Autobiography as a literary genre has received renewed attention. Critics begin to take an interest in defining it, describing its prominent characteristics, and outlining its historical development. Distinguishing between autobiography and "the genres of autobiographic writing such as the memoir, the private journal, and autobiographical fiction," critics define it as a "retrospective" narrative of a "story" of "personality" in which the author is the narrator and the protagonist (DiBattista \& Wittman, 2014, p. 3). Tracing its roots to the tradition of Christian confession, some critics find in Augustine's Confessions the earliest manifestation of the genre, "indeed, often as the first autobiography" (Becker, 2014, pp. 23, 33). Others divide the genre into modern and old autobiography, with the medieval output as a dividing line between the two and the "psycho-historical development of later centuries" as a distinguishing feature (Fleming, 2014, pp. 35, 36). Accordingly, modern autobiography explores subjectivity (the writer's consciousness and individuality) and expression (the artistic presentation of subjectivity); and the old form tends to focus on "exemplarity" (a demonstration of the generalized meaning of a particular life in its illustration of broad human or transcendental truths) like God, saints, prophets, religious miracles and mystical experiences (Fleming, 2014).

Interestingly, critics argue that the term autobiography was coined during the Romantic age and first used in the "hybrid" form of "self-biography" by writers like Isaac D'Israeli (in 1796), and by S. T. Coleridge, later on, to describe William Wordsworth's The Prelude, till William Taylor introduces the word "auto-biography" in his review of D'Israeli's work, and Robert Southey follows in his footsteps in 1807 (Wilson, 2014). Such coinage comes in response to the high pitch that subjectivity has reached during the Romantic era, where all types of writings, "not just of poetry and confession but criticism, philosophy, literary prefaces, journalism, and journal writing" are autobiographical (Wilson, 2014, p. 71). The Victorian type "tends to be more impersonal and less anguished and introverted than the Romantic self-chronicles" (DiBattista \& Wittman, 2014, p. 10). It strives for objectivity without necessarily fully achieving it; for some Victorian writers unconsciously expound personal life through an oedipal crisis (like Darwin and Mill), while others manage to turn autobiographic content into philosophical and meditative contemplations (like Newman) (Nord, 2014). The modern form of the genre continues in the contemplative mode, abandons "the linear convention of narrative" (DiBattista \& Wittman, 2014, p. 17), and authors become selective and subtle in expounding personal experience like Nabokov, who "does not tell the reader precisely what he has in mind, but a few elements [ultimately] present themselves quite clearly" to his readers (De La Durantaye, 2014, p. 176). The postmodern prototype, critics proclaim to be metafictional for its focus on the artistry of the text and its questioning of the role of language in reflecting experience (Madden, 2014).

Marmaduke Pickthall, whose fictional writings, especially his Near Eastern novels and short stories, can be categorized as autobiographic fiction like that of Charlotte Bronte and Charles Dickens, has also written two autobiographies that scholars choose to classify as memoirs or travelogues rather than set within the genre of autobiography. One of the two works, Oriental Encounters: Palestine and Syria, 1894-6 (1918), documents Pickthall's early adventures in the Levant and is described as "partially fictionalised" (Nash, 2017, p. 2), labeled as "fictionalised memoir" (Nash, 2017; Ashraf, 2017), and "a travelogue of the author's first visit to Syria and 
Palestine" (Long, 2014, p.137). The other autobiography, With the Turk in Wartime (1914), focuses on Pickthall's later venture into Turkey, is described as a "dramatic and sad memoir" (Murad, 2010, p. xxiii), but is more impoverished in critical reception than the other piece. Clark (1986), indeed, drops it altogether from his synopsis of Pickthall's Near Eastern works though he includes Oriental Encounters in his outline. While the anecdotal content of these two works skilfully resurges in the context of his novels, the interest of this article is in Pickthall's experience with the genre of autobiography. Following the researcher's book on him as a remarkable novelist of the early twentieth century who reveals in his fictional works postcolonial characteristics eighty years before the launch of postcolonialism in literature (Sadiq, 2016), Pickthall deserves attention as a writer of autobiography. The focus in the current essay will be on With the Turk in Wartime as an autobiographical work and on Pickthall's special use of the genre of autobiography.

\section{Discussion:}

Pickthall's autobiography, With the Turk in Wartime, is an intricate combination of old "exemplarity" and modern "subjectivity." While subjectively proclaiming his presence and identity within the work, he shifts the focus to serving Islam. Dismayed with the prejudiced reports that the English media promotes against Islam and the Muslim Turks, Pickthall decides to visit Turkey on what Seddon (2017) calls "a fact-finding mission" (p. 93), and Nash (2017) describes it as a "journalistic crusade on behalf of Turkey"( p. 2). Pickthall's autobiography is a documentation of the visit during which he probes the events of the Balkan massacres and comes up with his findings in this autobiography. Managing to find evidence to falsify media reports, Pickthall goes beyond that to promote a positive image of Islam and the Muslim peoples, both Turks and Arabs. In a manner that echoes his postcolonial leanings in his Near Eastern novels, he suggests ways to politically empower Islam and keep the Muslim world united against what he deems a crusading war against its faith. His autobiography becomes a tract to support the religious cause of Islam poilitcally.

The subjective mode of autobiography reaches its zenith in the Romantic tradition, is challenged into a more impersonal stance by Victorian writers and philosophers, and finally becomes both anti-narrational and contemplative in the modern literature of the twentieth century. Pickthall seems to have his intake of all three traditions. Wilson (2014), in "Romantic Autobiography," argues that autobiography is a romantic form that takes a confessional turn, shares its content through "the intimacy of the first-person speaker," and its "author" is both the "narrator" and "the subject of the narrative" (p. 72). Pickthall (1914) shares with the Romantics their first-person, subjective speaker, for he is fully present in the text in his proper name as "Monsieur Pickthall," which leaves no doubt of the speaker's (and the protagonist's) identity (p. 131). Pickthall also uses the subjective mode to introduce himself as a lover of Islam and the Arabs, to boast of knowing Arabic and of being able to read the Quran with the proper intonation of voice. He further declares his goal to learn the Turkish language and to get to know the Turks as well. On the other hand, Pickthall partakes of the Victorians' objective strain, but not their oedipal crisis that Nord (2014) discloses, in her essay "Victorian Autobiography: Sons and Fathers," as characteristic of the autobiography of that age. Pickthall does not challenge the father figure he lost early in life as a child of five but challenges the British government's Balkan policy and its anti-Muslim orientation.

Arab World English Journal for Translation \& Literary Studies 
The Romantic and Victorian veins are enriched in Pickthall's autobiography by a modern streak. Madden (2014) argues that starting with Montaigne, the genre begins to oppose extended narration and give preference to meditation, not just experience, for "Montaigne, shies away from the narrative mode in communicating the 'knowledge' that he hopes to keep alive" after his demise (p. 224). Madden also distinguishes between "the traditional memoir" that usually "allies itself closely to the novel (...) and the short story," and the "new memoir" in which narration becomes "subservient to idea," and its authors often "engage in direct philosophical thinking" (p. 225). Interestingly, Pickthall (1914) explains in the introduction to this autobiography his selectivity in narration and dispensation with elaborate descriptions and chronological details. He writes of having "here and there, condensed a conversation, or merged a number of occasions into one; and, leaving out the usual tourist business of description," he "treated mainly of the things that struck" him "as significant" (p. xiii). Pickthall shares with the modernist their elation of the idea at the expense of narration. Dispensing with daily, chrononoogical reports, he prefers to investigate political events, scrutinize cultural ideologies, and present his findings to serve his argument for the cause of Islam. He is more concerned with the political and ideological side of experience than with storytelling. Hannay (2014), picking up a nineteenth-century and a twentieth- century authors, Kierkegaard and Nietzsche, finds that these two authors write according to the occasion and remove unnecessary details of life. They share an identical goal of distinguishing themselves as living writers who differ from the version of selfhood portrayed in their fictional works. Pickthall also writes this autobiography according to an occasion, though not for a personal purpose, but rather for support of Islam. He visits Turkey for four months and writes this time-and-place-bound autobiography to defend the Turkish people against exaggerated reports of massacres and atrocities in the Balkan states. In brief, Pickthall's autobiography, With the Turk in Wartime, is a complex combination of Romantic subjective, Victorian impersonal, modern anti-narrational, contemplative and selective modes. This article intends to explore the work according to these features and highlight how Pickthall simultaneously leans towards old "exemplarity" in his autobiography and employs the genre for the service of Islam.

Pickthall's subjective presence in this autobiography becomes evident as he professes himself a lover of Arabs, Muslims, and Islam. His interest in, and sympathy with, the Muslims is established from the start and enforced through till the end of the book. Indeed, on his very first arrival in Turkey, he declares that he "prefer[s] the meanest lodging in a Muslim village to a cosmopolitan hotel in Pera," the Christian town (Pickthall, 1914, p. 22). He informs the man who would help him find such a place that he is not "a proper Englishman" with "the chosen pastimes" of his "race," for these "had no delight for" him, and that he is a person who led an "Arab life" earlier and developed "love of Muslims" (p. 23). Contrary to this self-presentation, some critics perceive Pickthall through a colonial lens and argue that "[f]or much of his time in England, Pickthall seems to remain wedded to a highbrow English lifestyle, with walking, gardening and recreation abroad as his main pastimes" (Ansari, 2017, 44). Indeed, acting similarly to his earlier experience in Palestine when he put on the native garb and mixed with the Arabs, Pickthall (1914) declares that his current wish is to know the Turks closely and learn their tongue. Towards the end of his stay, he boasts that his Turkish is getting fluent, and he fully pronounces his political support of the Turks. But the pride he takes in his mastery of Arabic is unequaled and becomes evident in his frequent reports of the impression such talent has on others. For example, upon "discovering" 
that Pickthall "knew some Arabic," and "could read texts and holy names upon the walls," of the Aya Sofia mosque, a khoja ("Muslim clergyman") showed him "a fine manuscript of the Koran (. ..) and made him read a page aloud in the right tone of voice" (pp. 16-17). On being told by Rifaat Bey (a Turkish friend of Pickthall) that Pickthall "knew Arabic, and was a lover of Islam," another khoja becomes quite eager to discuss the future of Turkey with him (p. 37). Though not a pronounced Muslim at the time of the visit to Turkey, for he speaks of the Christians of the land as "coreligionists" (p. 63), Pickthall affirms that he "hate[s] like a good Muslim," "the faith of Mammon, God of Europe" that a particular Turkish book seemed to "preach" (p. 78). The book, "a work of Mammon," is "pernicious" and goes "against true religion" because it "put this transitory world above the other, and made no mention of the power of God" (p. 76). He also affirms that "[a]s a lover of Islam," he is averse to seeing another revolution taking place in Turkey (p. 136) because it would injure the political stability strongly needed for the empowerment of Islam. In brief, Pickthall uses the Romantic subjective voice in this autobiography to establish himself as a lover of Arabs, Muslims, and Islam. Such a base is vital for the keen and ardent investigation of the events of the Balkan massacres and the subsequent call for the political empowerment of Islam in the modern world.

Pickthall's statement of objectives in the introduction to this autobiography preludes the two key moves in it, the subjective establishment of identity and the exemplary move towards the service of Islam. He states: "I made up my mind to go to Turkey for a few months in order to escape an atmosphere which sickened me. The English Press and public had (...) responded with fanaticism to the cry of a Crusade against the Turk raised by some cunning Balkan rulers; and that fanaticism had been fostered (. . .) by British statesmen" (p. ix). Exposing fanaticism in England against the Muslim Turks, Pickthall elaborates on how painful this was to him. He affirms that "solidarity of Christendom against a Muslim power (. . .) broke the heart of Englishmen who loved the East" (p. ix). Pickthall is even more specific as to indicate that he is one such Englishman. He narrates how it "had been [his] lot in early youth to be immersed in the unconsciousness of the old East, to receive its spirit for a season and to know its charm" (p. xi). His assertion seems to negate Nash's (2017) argument that the allegiance with the Arabs is made "in retrospect" by "the mature Pickthall" when he converts to Islam (pp. 12-13). Indeed, in this introduction and before his conversion, Pickthall affirms that if people are thinking of Europe, he is thinking of the East,

"Oh, Europe! Europe! Is it all the world? Nobody thought of Asia looking on. And if one mentioned it, he was informed that Asia did not count, being uncivilised and, what appeared to many a conclusive argument, outside the pale of Christianity" (p. x).

Establishing an unswerving identification with the Muslim world early in the introduction, Pickthall will delineate in the course of this autobiography the positive aspects of that world and its potential for progress.

Yet despite his personal, subjective voice, Pickthall keeps within this interestingly modern, autobiography an objective balance in documentation which the English Press has not maintained in its reports about the Balkan war. One sign of balance in Pickthall's attitude resides in identifying "two kinds of Christianity: one, which would limit its benevolence to Christian peoples; the other, 
which regarded the world with its creeds and races as the theatre for Christian charity and Christian justice" (p. x). This distinction is necessary because Pickthall wishes to avoid semblance of prejudice in his response to the religious conflict in Turkey once he starts investigating it. He wishes to set up an example of justice and to implicitly condemn fanatic attitudes. He detects partisan Christianity in the Russian and Balkan territories, and indicates it "could claim adherents" in England too (p. x). The British Press has unjustly affirmed atrocities and fanaticism of the Turks against the Bulgars. In the course of this autobiography, Pickthall will expose the imbalance in the British Balkan policy and its unjust incrimination of the Muslim Turks and unscrupulous absolvement of the Bulgars. He will also elaborate on the historical origin of such religious bias.

Pickthall travels to Turkey to see for himself how things stand. Although his autobiography is not a chronological report of personal experience, the author preserves a traditional narrative frame of having arrived at the port, stayed for a short while at the Christian town of Pera, moved to the countryside, spent few months there learning the language and interacting with the Turks, and finally returns home. Within this general frame, Pickthall has his modern innovative tactics. His apology in the introduction for having "here and there, condensed a conversation" (p. xii) is a helpful hint to a valuable technique he will employ in this autobiography, during which dialogue becomes an essential tool in establishing truth. Clark (2017) expresses his approbation of Pickthall's handling of "dialogue" in his novel Said the Fisherman. The current paper will highlight the value of objective representation that dialogue lends to this autobiography. It allows all points of view to operate and have a simultaneous presence in the text in a manner akin to the author's practice in his Near Eastern fiction underscored in the researcher's book, Marmaduke Pickthall Reinstated: What Canon? (Sadiq, 2016). But his conversational tactic also signals another significant element of the genre of modern autobiography, that of selectivity instead of detailed narration and chronological documentation. It enables Pickthall to focus on pertinent human encounters, to inquire and argue with people who speak of the massacres of Turkey. He introduces such conversations into this autobiography to bridge the gap that the English media has created upon excluding the Turkish point of view from hearsays of the conflict. Pickthall's long debates with various types of people help him establish balance against the exaggerated media reports of the presumed cruelty of the Muslim Turks.

In addition to conversations, Pickthall has recourse to two other techniques to achieve his goals in this autobiography. One is engaging the historical perspective, and the other is relating personal experience and observations. History enables Pickthall to argue with people in an objective way that excludes the personal perspective and helps establish facts. The author is fully conscious of the value of this technique, for he contends that the subject of the massacres is one "on which no one ought to speak or write who has not personal knowledge of the peoples of the Near East, and some acquaintance with Mohammedan and Turkish history" (p. 63). Pickthall's conception of historical perspective is allied with a socio-cultural background in its operation, which points in the direction of his third technical aspect in this work, that of personal experience and observation. Significantly, Pickthall manages to free this last technique from the subjective stance and transfigures it into a scientific mode of direct experimentation and recorded observations that precede the establishment of facts in science. The three technical tools convert a personal autobiographic context into an impersonal account.

Arab World English Journal for Translation \& Literary Studies

ISSN: 2550-1542 | www.awej-tls.org 
The first of Pickthall's series of "significant" conversations comes in an encounter with a Christian Turk that the author meets on board the steamer as he travels into Turkey. The man starts with a discriminatory stance against the Muslim Turks, during which he attempts to cover up for "the atrocities committed by the Bulgarians" against the Muslim Turks "in Macedonia" (p. 5). He claims that he has "information" about "Dede-Aghach, where the Turks have slaughtered all the Christians" (p. 6). Pickthall counters his claims by informing him that "respectable Europeans" have "provided evidence upon the horrors committed by Bulgarian troops" there (p. 6). Observing that Pickthall is well informed, the man modifies his accusations. He declares that the Turks often begin a narrow-scaled massacre by killing a small number of people, which incites the Christian Bulgars to ask the Muslims for total conversion to the Christian faith or to exit the country. If Muslims fail to comply, they would be massacred. The case is so because he believes, Christians have suffered from the fanaticism of Muslims. Pickthall deflates this accusation through a historical perspective and informs him that "Latin Europe" was intent on destroying the Eastern Christians had it not been for the Turkish conquest and "its toleration" (p. 6). The man must admit that what Pickthall is "saying now is very true" (p. 6). He even admits that though he has received news of "another revolution and attacks on Christians in Constantinople," he, who is "of the country," and being "well acquainted with the Turkish character," finds himself "wondering how such false reports can be believed" (pp. 6-7). Dialogue thus enables Pickthall to deflate claims of Muslims' intolerance towards Christians in Turkey and to expose the Christians' involvement in acts of religious fanaticism and violence.

Pickthall assesses the Christian Turk's initial posture as "a product of the policy which Europe has pursued for a whole century, of interference on behalf of Ottoman Christians, and missionary efforts for their education and advancement" (p. 7). The man and "his kind," Pickthall believes, have done "mischief" to Turkey by presenting "information" in a way that gives "a false impression" about the situation in the country (p. 7). Though "still technically . . an Ottoman subject," the man "pays allegiance to foreign governments" (pp. 7-8). He and his type "desired the downfall of the Turks and would have liked to see a Christian king - no matter which - arrive as conqueror" (p. 14). Western interference in Turkey proves to be a significant cause of dissent between diverse religious groups.

The second engagement in "significant" conversation enables Pickthall to establish balance against his indictment of the Eastern Christians without dropping his argument against the presumed fanaticism of the Muslim Turks. It comes while Pickthall was still stranded at Pera, waiting for the realization of the countryside accommodation. It occurs with his Turkish teacher, a Roman Catholic Arab who never "heard of Turkish fanaticism - Christian though he was, and mixing, as he did, continually with Mohammedans" (p. 31). The testimony further helps disprove the presumed Muslim intolerance in Turkey. It simultaneously shows the author's keenness to maintain balance in recording conversations of Eastern Christians, be they tolerant or biased.

The power of personal experience and observation comes into play as Pickthall begins to tour the major cities of Turkey. It enhances the technique of conversation in probing the massacres and that of historical perspective in arguing and documenting facts. Visiting at Aya Sofia mosque, Pickthall notices the presence of "refugees from Thrace and Macedonia," cities that have suffered 
from "Christian onslaught." Although most refugees have "been removed to camps (...) upon the coast of Asia, a few family groups" remain "huddled together in the great closed porch" of the mosque (p. 16). "Their appearance might well have roused fanaticism in Mohammedans" (p. 16). Nevertheless, it has not. A Muslim khoja "very courteously" asks Pickthall "to take off his hat" before entering the mosque (p. 16). He informs him that has it been a fez, he "must have kept it on" (p. 16). The rule is a matter of dress code, not of religious bias against non-Muslim. Pickthall also affirms that "[n]o other word or look addressed to me, on that or any other of my wanderings, suggested that the difference of faith was even recognised" (p. 16). Personal contact with Muslim Turks, including their clergymen, attests to the absence of fanaticism in their attitude towards nonMuslims even though the nearby sight of dislocated and victimized families would have incited it. Muslims are no aggressors and are attacked and massacred by the Bulgars at Thrace and Macedonia. Direct personal experience and observation help Pickthall establish such facts within the context of this autobiography.

The discovery of Muslim persecution in Turkey does not lead Pickthall to neglect the other side of the case, which is the possiblity Muslim aggression in Turkey against the Christians of the land. The author affirms in the introduction to this autobiography his unbiased attitude, his commitment to search for truth be it "good or evil" (p. xiii). He proves true to his word when he reports his "conversation" with an "old-fashioned," yet "progressive" khoja, who speaks of the old regime as despotic and regards "despotism irreligious and disastrous to Islam" (p. 36). Following such reference to tyranny, Pickthall objectively reports his findings regarding the massacres, two of which "were performed by savage Kurds at the direct command of Abdul Hamid II - a Sultan whom the Turks themselves deposed with ignominy for his cruelty" (p. 65). The autocratic dictates of tyranny have forced some Muslim groups to commit aggression against Christians. It seems that this is the side that the English media has inflated, and ignored, in the meanwhile, "that the name of Serbs and Bulgars was a byword for atrocity in Medieval Europe" whereas "massacres of peaceful Christians by Mohammedans were practically unknown" at that time (p. 64).

The author's elaborate reference to Medieval times indicates his technical reliance on the historical perspective. Pickthall continues to engage this technique side by side with the other two. He reports that

"since the historic interview of Peter the Great with Cantimir, Voivode of Wallachia, when the latter told the Czar what profit might with patience be derived from a close study of the privileges of self-government enjoyed by Christians in the Turkish Empire, Russia has been steadily at work to ruin Turkey by tampering with Turkish Christians and rousing their fanaticism" (p. 65).

"Except in two cases," mentioned above in the context of the authoritarian regime, "every massacre has been deliberately provoked" (p. 65). Pickthall does not hesitate to report that on provocation Muslim Turks became violent. However, he insists: "If Russia had never existed, or at least had never interfered in Turkish politics, Ottoman Muslims and Ottoman Christians might long ere this have formed a happy and progressive nation" (p. 66).

Arab World English Journal for Translation \& Literary Studies 
Pickthall's probing into the massacres through human encounters and debates prevails in this work. The following conversation occurs with two elderly men on a boat trip from Stamboul to Haidar Pasha. Pickthall overhears the two men discussing the Anglo-Russian alliance as pure fanaticism against Muslims. Consequently, he asks a friend to introduce him to them. This "view of modern Europe, as old Christendom, united by fanatic hatred of Islam was nothing new" to Pickthall (p. 52). But he is eager now to appease the two men by indicating that the case is not so absolute in England that happens to have large Turcophile groups within the educated English classes. Unfortunately, such groups are not "allowed a public hearing" (p. 55). Their sympathetic perspective does not reach out to the public that remain ignorant about the situation in Turkey. Prejudice in the Press is the cause for such silencing. It originates in the political parties of the country that manipulate the Press and allows the publication of "long diatribes in favour of the Balkan States" while "the Turkish point of view was never even stated" (p. 54). Pickthall's debate with the two men enables him to voice his critique of the British policy towards Turkey in general and the Balkan massacres in particular. His critique extends to include the misconduct of the British people abroad such as the "self-righteousness," of "diplomats, (...) missionaries and many private individuals in Turkey" who have a way of talking as if England were a perfect country. The honesty of both declarations enables him to win the speakers over before they leave. But he balances out the critique by affirming that the English people are indeed "well-meaning" though they might seem "unamiable" (p. 55). As Kökoğlu (2017) argues, Pickthall "never betrays Englishness" (p. 200). Much earlier in the Pickthall scholarship, his biographer Fremantle (1938) nicknamed him a "loyal enemy" to describe his intricate position as a politically-dissident, cultural ally.

Pickthall's following conversation comes with the friend who has introduced Pickthall to the two "old-fashioned men" earlier (p. 52). The friend pursues their very same theme of English fanaticism though he tackles it from a more educated perspective than theirs. He distinguishes between the liberal and the conservative political parties in England and argues that the liberal party is fanatic and hates Muslims, unlike the conservative one. Implicitly agreeing with him, Pickthall explains that conservatives care about colonial affairs and liberals about local issues. Still, he admits that the British government has not dealt fairly with the Balkan case. Pickthall's interlocutor gives the Turkish perspective of the case. The Turks believe that England is wrong to support Russia that will become strong and a threat to its dominance later on. The man even describes the English government as "treacherous," though he admits that the Turkish people do trust the common Englishman.

To counter the English media's denial of the Muslims' extermination in the Balkans, Pickthall asks his Turkish friend Rifaat Bey to help introduce him to eyewitnesses and wellinformed figures about the massacres. However, he makes it clear to this friend that accessing officials in the government is a useless procedure because the Turkish government has accepted "the wholesale slaughter of Mohammedans as part of the fixed policy of Europe" (p. 63). He even informs his friend of "an interview with the Minister of the Interior" who "after hearing all" Pickthall "had to say (. . .) had begged" him "to resign" himself (p. 63). Such dismissal does not seem to dishearten Pickthall from his "aim to get information on the Macedonian horrors, which might enable" him "to silence certain anti-Muslims" in England (p. 71). In his usual manner, he 
interviews some people and is convinced "beyond a doubt that neither the Turkish government nor any individual Turk had invented, or even knowingly exaggerated anything in the reports of massacres which had been issued by the Committee for the Publication of the Balkan Atrocities," even though such reports "were being denied by writers in the English Press" (pp. 71, 62). A seeming exception to such denial proves to be equally false. A Times magazine's report admits "that there had been murders," on the Muslim side "but no more than were customary in all warfare. The writer put the number (. . .) at 600" people. To such a report, Pickthall responds: "I should have liked to write a stiff reply to this concoction, but lacked other authority than the published Turkish reports, which were treated in the Times and elsewhere as preposterous" (pp. 62-63).

Distortion of facts extends beyond the massacres to include cultural ideologies and attitudes. Pickthall uses a conversation with two Ottoman Greek girls to expose how Christians of Turkey misconceive of their Muslim compatriots. The girls come "from a village up the Bosphorus-fearless, self-respecting girls who earned a modest living by their work as dressmakers, journeying from house to house" (p. 81). They inform Pickthall that "they were petted by the Turkish ladies, and treated by the men with all respect" (p. 81). However, such kind and proper treatment does not eliminate a sense of essential negativity they and their parents have about the Muslim Turks, for "they dared not let their parents know that they had ever been employed in Muslim houses. Had the fact been suspected in their village they would have been ostracised, perhaps stoned" (p. 81). Their fanaticism is further exposed when the girls "owned to being indebted to the Turks for kindness," yet "they hated them (. . .). and did not see how any Muslim could really be regarded by a Christian as a fellow-creature" (p. 82). Upon finding that Pickthall is an Englishman who "preferred the Turks," they wondered, "[w] wat was there in them to inspire liking? They were good-natured, truly; so were many animals. But were they not barbarians, and cruelly fanatical?" (p. 83). Ironically, the girls are not aware of their fanaticism. On being reminded of the Muslim kindness at the time of the outbreak of fire in their village, they admit that "the Muslims often did kind actions, which, however, could not blind a Christian to their utter and essential wickedness, the product of a false religion" (p. 83). Pickthall assesses their attitude against Islam and Muslims as one of "pure fanaticism" (p. 85). Their religious prejudice reaches extremity when they say that "the great persecution of Mohammedans at that time going on in Macedonia was justified upon religious grounds" (p. 86). Pickthall believes that the "instructions which [the girls] had received from priests and parents" have curtailed the chance that "their own experience would have made them tolerant" (pp. 86, 85). This cultural antagonism towards Muslims, Pickthall clarifies, is the result of anti-Turkish propaganda by Russia and then by Hellenic culture. It is the Ottoman Greeks that prove to be fanatic through this debate. Still, in his care for balance and justice, Pickthall acknowledges that some ignorant Muslims adopted the habit of "fanaticism" because of Europe's interference on behalf of Eastern Christians. Pickthall's comment on the case is that "ignorant Christians are as fanatical as ignorant Muslims" (p. 81). Fanaticism is a detestable social malady that Pickthall associates in this autobiography with historical and cultural ignorance.

Absolving the proper Muslim Turks from accusations of fanaticism, Pickthall finds it necessary to clear Islam itself from such charge. Tolerance stands on the opposite side of 
fanaticism, and Pickthall strongly believes that it will put an end to dissent in Turkey. The author emphasizes that "Islam" is "no less tolerant than Christianity" and "it is not a foe to human progress," but it "has been widely and sententiously misrepresented, even by a section of its own adherents" (p. 194). "The Coran" should be read in a "carefully collated" manner for its "pros and cons for toleration - at any rate of Jews and Christians" to be understood (p. 194). The "pronouncements (fetwahs) of Sheykhs-ul-Islam and learned judges will be found now leaning towards the widest tolerance, now wearing the dark colour of extreme fanaticism, according (. . .) as Christendom attacked the Muslims or kept peace with them" (p. 195). "A learned sheykh explained the matter thus to" Pickthall:

"A Christian who loves Muslims and respects their faith must be counted as a Muslim by all true believers everywhere. He is in the way with us, bound on the same journey, and to hold aloof from him or flout him would be sin" (p. 195).

Pickthall finds a parallel to this speech of the sheikh with Gospel texts: "Other sheep I have which are not of this fold," and "[h]e that is not against us is for us" (p. 195). Such texts, Pickthall indicates, "have been overlooked by Christians," and hence arises their fanaticism (p. 195). But the result is that a "Christian who avowedly hates Muslims, or assails them, is naturally to be treated as an enemy" (p. 195). Otherwise, "the religion of the Muslim is more enlightened and progressive in the abstract, than that of the majority of Eastern Christians; which brings" Pickthall to the point that "El Islam is not a foe to human progress" (p. 196). Pickthall's attention to the idea of progress is crucial for his ultimate goal of politically empowering Islam and the Muslim peoples.

Much earlier in this autobiography, Pickthall starts establishing a positive image of Islam. To eradicate the negative notion of barbarism promoted against the faith and its adherents, he highlights the Muslims' potential for progress. An enlightened Muslim khoja, engaged in a conversation with Pickthall, "dwelt much upon the need of patriotic education, of encouragement of every local effort for self-government, as tending to relieve the Porte of the enormous burden left to it by the old tyrannical regime" (pp. 35, 36). He informs Pickthall that "Learned doctors of religion" advised the leader in establishing the new "Constitution" in Turkey, and "the theological students in the capital were its fierce supporters" (p. 36). "It is, therefore, a mistake to speak of El Islam as unprogressive save by force of circumstances" (p. 36), such as the dictates of tyranny. Elaborating on Islam's potential for advancement, Pickthall underlines its image as a religion of practical pursuits and worldly responsibility. He quotes a Muslim khoja saying, "God, the Almighty Maker of the world (...) did not intend good men to leave the world aside, resigning its affairs to rascals and to unbelievers" (p. 78). The Creator expects people to be active in the world and laid rules to guide them in the process. The Muslims' holy book has guidelnes "for the conduct of the faithful in the market-place, the seat of power, the battlefield and so on" (p. 78). Islam's consideration for practical involvement in the world is evident in its provision of rules to organize the running of political institutions, economic activities, military action and in its advocation of education and social progress.

Having defended Islam against accusations of fanaticism and underscored its tolerant nature and progressive outlook, Pickthall moves to call for political empowerment of Islam in the 
modern world. He finds it in the Ottoman Empire that was on the verge of collapsing due to being targeted at that time by Russia and some European powers, including England. However, such a suggestion is not established without explanation and justification, for Pickthall is aware that the Arabs are strong rivals of Turkey in this regard. His precaution leads to a comparison between the Arabs and the Turks in the book. Although he has been told in his debates with some Turks to appreciate the "advance Turks made over his beloved Arabs" (p. 91), Pickthall maintains an unswerving love and admiration for the Arabs. He has even "earned the reputation of an Arab partisan by attacking Turkish indifference upon the subject of the Arab grievances whenever" he "could get a chance" (p. 120). The "Arabs seemed to" him "to be the hope of Turkey. Their mentality, if limited, possessed an energy and a directness which was lacking in the Lazy greatness of the Turkish outlook" (p. 120). His "heated arguments with certain Unionists" (members of a political party in Turkey) "who wished to view" the Arabs "in the light of naughty children" testify to Pickthall's enthusiasm for the Arabs (p. 120). Such debates were exasperating, and he often "retired despairing till a friendly word" from a minister, "carried to Pickthall by a friend, assured" him "that the ruler thought as" he "did" (p. 120).

Despite his devotion to the Arabs, Pickthall wishes to see the Ottoman Empire remain intact. The case is so because he considers Turkey "a country in close touch with Europe," and the Turks are, therefore, "capable of understanding Europe and acting as interpreter[s]" to other countries within the Ottoman Empire (p. xii). Still, Pickthall does not give up on the Arabs nor wish to see them marginalized in the Empire. He replies to his Unionist interlocuter who inquires how he wishes to see the Arabs treated: "I should have liked to see them treated on equal footing with the Turks; to see both Turks and Arabs reinstated in that measure of self-government which was theirs under the early Sultans" (p. 120). Pickthall, indeed, opposes both the Turkish Unionist who would make "all the Arabs into Turks" (p. 119) and their opponents, the Liberals, who would see the British model in the colonies applied to the Turkish rule of the Arab world. Pickthall deems the model of "devolution" with "Governors" representing the "Sultan" within the Arab world as unfeasible (p. 118). He wants to see the Arabs in a state of self-governing as "provided by the law of El Islam" with their "communal and municipal institution (. . .) made efficient and responsible," instead of the present "encroachments of the central power" on them (pp. 120, 121). The Ottoman presence to him is a matter of convenience in foreign political relationships with the Europe, but the force of Islamic cultural orientation resides with the Arabs, not the Turks, for the modern Turks ought to learn Arabic rather than French. In his assessment of Pickthall in another context, Seddon describes him as "continuously pulled towards the East" both "culturally and spiritually," in the form of "romantic orientalism," which "was clearly manifest in his obsession with Arabic language and culture" (p. 99).

\section{Summing Up:}

Pickthall's With the Turk in Wartime is a unique, time-and-place-bound, subjectiveobjective, modern, and paradoxically old autobiography of exemplarity. The temporal and spatial boundaries of the work are a four-month visit to Turkey that he dedicates to investigating the Balkan massacres. Despite the modern exclusive touch in time and place, Pickthall employs the subjective voice common to this personal type of writing. Still, he manages to free it from the Romantic shackles of absolute self-centeredness. The voice becomes impersonal, and the content 
unbiased. The technical elements that the author employs lend the work its impartial bearings, reminiscent of the Victorian writers' attention to objectivity. The content is equally impersonal, mainly because it deals with the political scene and the Balkan massacres rather than the author's daily adventure in Turkey. Yet Pickthall goes beyond the Victorians in his autobiographic venture to become distinctly modern in his dialogic, anti-linear, anti-narrational mode and in limiting his selection for documentation to most pertinent events and conversations as well. Interestingly, such intricate intermingling of diverse literary traditions is employed to attend to exemplarity (Islam in this particular case), which is very much in keeping with the old, ideologically-oriented manifestations of the genre.

His visit to Turkey enabled Pickthall to investigate the massacres and deflate the biased reports of the English Press against the Turks and Islam. But the English media is not the sole fanatic assemblage at that time; the Eastern Christians of Turkey count as another. Pickthall argues with some of them to remind them of Turkey's historical contribution to religious diversity in the region; of the injustice of the European intervention in Turkey and the Levant that privileged the Eastern Christians against their Muslim fellow citizens and created dissent between the two sects. $\mathrm{He}$ also critiques the Russian self-serving, politically-targeted intervention that generated fanaticism.

Against the atmosphere of fanaticism and violence, Pickthall asserts the tolerance and the progressive nature of the Islamic creed. He calls for the continuation of the Ottoman Empire to politically empower Islam. His conception, nevertheless, recommends political independence for the Arabs within an internationally acknowledged and supported frame of an Ottoman Empire. His enthusiasm for Turkey is probably inspired by the sense of peace and freedom that Pickthall has experienced on visiting Palestine and Syria some twenty years before his Turkish venture. He has attributed the pleasant atmosphere there and then to the policy of the Ottoman sultans who do not directly interfere in running the Arab world and let it run itself instead. It seems that this conviction influences Pickthall's call for a continuation of that early situation. His political conception did not materialize, and the Ottoman Empire lost grounds soon after this call. His suggestion also has no significance in our modern times. Still, facts about the Balkan massacres that he has come up with and documented in this autobiography will always counter other voices and maintain balance in historical records.

Pickthall's intended readership is the anti-Muslim sets in England of his time. But his keen investigation and unbiased documentation lend this autobiography a historical worth that would last for generations. It establishes a sense of balance against the biased reports of the English media about the massacres; exposes the fanaticism of Europe and the Eastern Christian against Islam at that historic juncture; and affirms the tolerance of Islam and the educated Muslims.

\section{Conclusion:}

This article aimed at tackling Marmaduke Pickthall's With the Turk in Wartime as a autobiographical work that critics neglect despite the revived interest in this author and his works during the last decade. Pickthall has regained within contemporary scholarship some of his early esteem as a novelist but not as an autobiographer. The study attempted to grant him this overlooked 
privilege. It detected links that his autobiography has with several manifestations of this genre such as Romantic subjectivity, Victorian objectivity, Modern anti-linear module and old exemplarity. It also highlighted the use to which such combination is geared. Pickthall has transformed a highly personal form to a public account for the purpose of serving Islam.

\section{About the Author:}

Ebtisam Ali Sadiq: Professor of English at the Department of English language and Literature, King Saud University, Riyadh, Saudi Arabia. Studied Master at Loyola Marymount University in Los Angeles, California, and PhD at Wayne State University, Detroit Michigan. Promoted to the rank of Professor at King Saud University in 1997. Author of: Marmaduke Pickthall Reinstated: What Canon? And several articles on Romantic, Victorian and Modern Literature. ORCiD ID: https://orcid.org/0000-0001-5495-6612

\section{References}

Ansari, H. K. (2017). Pickthall, Muslims of South Asia, and the British Muslim Community of the Early 1900s. In G. P. Nash (ed.), Marmaduke Pickthall: Islam and the Modern World (pp. 23-46), Brill.

Ashraf, A. (2017). A Vehicle for the Sacred: Marmaduke Pickthall's Near Eastern Novels. In G. P. Nash (ed.), Marmaduke Pickthall: Islam and the Modern World (pp.182-195), Brill.

Becker, A. H. (2014). Augustine's Confessions. In M. DiBattista, \& E. O. Wittman (eds.), The Cambridge Companion to Autobiography (pp.23-34). Cambridge University Press.

Clark, P. (1986). Marmaduke Pickthall: British Muslim. London: Quartet.

Clark, P. (2017). Foreword: Pickthall after 1936. In G. P. Nash (ed.), Marmaduke Pickthall: Islam and the Modern World (pp. vii-xiii), Brill.

De La Durantaye, L. (2014). The True Purpose of Autobiography: Or the Fate of Vladimir Nabokov's Speak, Memory. In M. DiBattista, \& E. O. Wittman (eds.), The Cambridge Companion to Autobiography (pp. 165-179). Cambridge University Press.

DiBattista, M., \& Wittman, E. O. (2014). Introduction. In M. DiBattista, \& E. O. Wittman (eds.), The Cambridge Companion to Autobiography (pp.1-20). Cambridge University Press.

Fleming, J.V. (2014). Medieval European Autobiography. In M. DiBattista, \& E. O. Wittman (eds.), The Cambridge Companion to Autobiography (pp. 35-48). Cambridge University Press.

Fremantle, A. (1938). Loyal Enemy. London: Hutchinson.

Hannay, A. (2014). Kierkegaard and Nietzsche. In M. DiBattista, \& E. O. Wittman (eds.), The Cambridge Companion to Autobiography (pp. 119-132). Cambridge University Press.

Kökoğlu, F. (2017). Becoming Woman and Gender Typologies in Marmaduke Pickthall's Oriental Fiction. In G. P. Nash (ed.), Marmaduke Pickthall: Islam and the Modern World (pp.196230). Brill.

Long, A. C. (2014). Reading Arabia: British Orientalism in the Age of Mass Publication, 18801930. New York: Syracuse University Press.

Madden, P. (2014). The 'New Memoir. In M. DiBattista, \& E. O. Wittman (eds.), The Cambridge Companion to Autobiography (pp. 222-236). Cambridge University Press.

Murad, A. H. (2010). Foreword to The Early Hours by Marmaduke Pickthall. The Cambridge: Muslim Academic Trust. 
AWEJ for Translation \& Literary Studies Volume, 5 Number 4. October 2021

In a Melting Pot of Autobiography: Pickthall's With the Turk in Wartime

Nash, G. P. (ed.). (2017). Introduction: Pickthall, Islam and the Modern World. In G. P. Nash (ed.), Marmaduke Pickthall: Islam and the Modern World (pp. 1-22). Brill.

Nord, D. E. (2014). Victorian Autobiography: Sons and Father. In M. DiBattista, \& E. O. Wittman (eds.), The Cambridge Companion to Autobiography (pp. 87-101). Cambridge University Press.

Pickthall, M. (1918). Oriental Encounters: Palestine and Syria (1894-5-6). London: Collins.

Pickthall, M. (1914). With the Turk in Wartime. London: Dent.

Sadiq, E. (2016). Marmaduke Pickthall Reinstated: What Canon? Singapore: Partridge.

Seddon, M. S. (2017). Pickthall's Anti-Ottoman Dissent: The Politics of Religious Conversion. In G. P. Nash (ed.), Marmaduke Pickthall: Islam and the Modern World (pp. 91-105), Brill.

Wilson, F. (2014). Romantic Autobiography. In M. DiBattista, \& E. O. Wittman (eds.), The Cambridge Companion to Autobiography (pp. 71-86). Cambridge University Press.

Arab World English Journal for Translation \& Literary Studies 